\title{
PERANCANGAN SISTEM INFORMASI MANAJEMEN KEANGGOTAAN PERGURUAN SILAT BERBASIS WEB (STUDI KASUS KELUARGA PENCAK SILAT NUSANTARA RANTING GOR RAWAMANGUN)
}

\author{
${ }^{1}$ Varra Meylanie Dewi1*, ${ }^{2}$ Agus Sulistyanto, ${ }^{3}$ Anton Zulkarnain Sianipar \\ ${ }_{1,2,3}$ Program Studi Sistem Informasi, STMIK Jayakarta, \\ Jl. Salemba I No.10, RT.4/RW.6, Kenari, Senen, Jakarta Pusat, Dki Jakarta, Indonesia \\ *e-mail:vmeylaniedewi@gmail.com,agus.sulistyanto@gmail.com,antonz@stmik.jayakarta
}

Received: 2021-07-19, Revised: 2021-08-10, Accepted: 2021-08-20

\section{Abstrak}

Keluarga Pencak Silat Nusantara merupakan salah satu perguruan silat yang ada di Indonesia sejak tahun 1968. Di cabang Gelanggang Olahraga Rawamangun perguruan silat ini masih menggunakan sistem pengelolaan data yang manual berupa alat tulis dan kertas, cara tersebut kurang efektif dimasa sekarang teringat banyaknya data anggota yang akan mendaftar tiap tahunnya untuk masuk ke perguruan silat. Sehingga bagian keskretariatan selaku penerima pendaftaran anggota baru merasa kesusahan dalam menginput data yang nantinya diarsipkan dalam tumpukan kertas dan memakan banyak tempat serta kemungkinan untuk data hilang sangat besar. Kendala lain yang dihadapi saat ini adalah sulitnya mengetahui data masing-masing anggota lama dan tingkatan anggota tiap cabang. Tujuan penelitian ini adalah membuat sistem informasi manajemen keanggotaan dengan metode Waterfall dan menggunakan Unified Modeling Language (UML) untuk pemodelan terstruktur. Dari penelitian ini dapat dihasilkan sebuah sistem informasi manajemen keanggotaan perguruan silat berbasis web pada Keluarga Pencak Silat Nusantara,

Kata kunci: Keluarga Pencak Silat Nusantara, Sistem Informasi, Pengelolaan Data, Pencak Silat, Web.

\begin{abstract}
Keluarga Pencak Silat Nusantara is one of the martial arts colleges in Indonesia since 1968. In the Rawamangun Sports Center branch, this martial arts college still uses a manual data management system in the form of stationery and paper, this method is less effective today with the large number of member data to be submitted. register every year to enter a silat college. So that the secretariat as the recipient of new member registration feels that in inputting data which will be archived in a pile of paper and takes up a lot of space and the possibility for data to be lost is very large. Another obstacle faced at this time is the difficulty of knowing the data of each old member and the level of members of each branch. The purpose of this study is to create a membership management information system with the Waterfall method and use the Unified Modeling Language (UML) for structured modeling. From this research, a web-based martial arts college membership management information system can be produced at the Keluarga Pencak Silat Nusantara.
\end{abstract}

Keywords: Keluarga Pencak Silat Nusantara, Information System, Data Management, Martial arts, Web.

This work is licensed under a Creative Commons Attribution 4.0 International License. 
DOI: 10.52362/jmijayakarta.v1i4.500

\section{PENDAHULUAN (Introduction)}

Salah satu perguruan pencak silat yang berkembang di daerah Jakarta Timur tepatnya di GOR Rawamangun adalah perguruan pencak silat yang bernama Keluarga Pencak Silat Nusantara atau lebih dikenal dengan sebutan KPSN. Seni budaya yang juga mempelajari tentang seni beladiri ini tidaklah dapat berdiri dan berkembang tanpa adanya suatu manajerial atau organisasi dalam kelompok tersebut, Maka dari itu demi perkembangan dan kelangsungan hidup perguruan silat, Keluarga Pencak Silat Nusantara juga perlu memiliki struktur manajemen yang berjalan sesuai dengan program kerja dari masing-masing wilayah. Awal mulanya Keluarga Pencak Silat Nusantara di daerah Jakarta Timur ranting GOR Rawamangun adalah sebuah cabang tunggal, yang membawahi bermacam wilayah ranting, yaitu Ranting SDN 16 Duren Sawit, Ranting SDN 06 Klender, Ranting SMPN 77 Jakarta, Ranting SMA Negeri 72 Jakarta dan Ranting SMA AlGhurabaa. Pada masa itu Keluarga Pencak Silat Nusantara ranting GOR Rawamangun mengalami penurunan yang sangat drastis dalam bidang pelaksanaan fungsi manajemen keanggotaan yang belum berjalan dengan optimal dan kurang berjalan dengan baik.

Setiap organisasi baik dalam skala besar maupun kecil dapat terjadi perubahan-perubahan kondisi yang dipengaruhi oleh faktor-faktor lingkungan eksternal dan internal organisasi. Dalam menghadapi perkembangan dan perubahan yang terjadi maka diperlukan suatu manajemen kenggotaan yang baik dalam berorganisasi. Manajemen keanggotaan organisasi yang ada dalam Keluarga Pencak Silat Nusantara ranting GOR Rawamangun belum ada suatu kejelasan dari fungsi manajemen keanggotaan yang dijalankan dalam lingkup pengurus organisasinya serta kelengkapan data para anggotanya. Kejelasan suatu fungsi manajemen keanggotaan sangatlah penting demi berjalan dan berkembangnya suatu organisasi.

\section{TINJAUAN LITERATUR (Literature Review)}

\subsection{Perancangan}

Perancangan adalah penggambaran, perencanaan dan pembuatan sketsa atau pengaturan dari beberapa elemen yang terpisah ke dalam satu kesatuan yang utuh dan berfungsi.

Langkah-langkah tahapan perancangan yaitu:
a. Menyiapkan rancangan sistem yang terperinci
b. Mengidentifikasi berbagai alternatif konfigurasi sistem
c. Mengevaluasi berbagai alternatif konfigurasi sistem
d. Memilih konfigurasi terbaik
e. Menyiapkan usulan penerapan
f. Menyetujui atau menolak penerapan system

\subsection{Sistem Informasi Manajemen}

Secara umum Sistem Informasi Manajemen adalah suatu sistem yang dipakai dalam pengolahan dan pengorganisasian data serta informasi yang mempunyai manfaat dan digunakan sebagai pendukung keberjalan tanggung jawab atau tugas suatu organisasi.

Definisi lainnya menyatakan bahwa sistem informasi manajemen yaitu sistem yang dipakai oleh organisasi/perusahaan dalam pengelolaan segala transaksi yang berkaitan dengan fungsi manajemen. Pengelolaan transaksi ini bisa dipakai sebagai acuan dalam proses pengambilan keputusan.

Disamping dua pengertian diatas, sistem informasi manajemen dianggap sebagai suatu sistem informasi yang memproduksi output yang diperoleh dari input yang masuk dan melalui bermacam proses lainnya. Hasil yang diperoleh melalui proses itu kemudian dipergunakan untuk pencapaian suatu tujuan pada aktivitas manajemen di organisasi/perusahaan.

\subsection{Web}

Web atau istilah lengkapnya World Wide Web (WWW) sering disebut juga website atau situs. Website dapat diartikan sebagai kumpulan halaman yang berisi informasi data digital baik berupa 
DOI: 10.52362/jmijayakarta.v1i4.500

teks, gambar, animasi, suara dan video atau gabungan dari semuanya yang disediakan melalui jalur koneksi internet (Rohi Abdulloh, 2018:1).

Menurut (Solichin, 2016:4), web merupakan bagian dari layanan yang dapat berjalan diatas teknologi internet. Web dapat diakses dengan adanya web server sebagai penyedia halaman web. HTML sebagai bahasa baku dan HTTP sebagai jalur pengiriman dokumen web.

\section{METODE PENELITIAN ( Research Method)}

\subsection{Metode Pengumpulan Data} berikut :

Dalam penelitian ini cra mengumpulkan data dilakukan dengan metode antara lain sebagai

\section{a. Metode Observasi}

Untuk melengkapi data yang diperoleh, maka dilakukan pengamatan dan penelitian serta menganalisa semua data yang diperoleh untuk mengetahui dan melihat secara langsung proses pengelolaan kegiatan tersebut sehingga penulis dapat menganalisa permasalahan dan membuat solusi atas permasalahan yang terjadi saat ini. Observasi dilakukan di sekretariat Keluarga Pencak Silat Nusantara ranting Gor Rawamangun.

b. Metode Wawancara

dilakukan untuk mendapat informasi yang dibutuhkan untuk pembuatan sistem berupa kegiatan tanya jawab terhadap pelatih dan anggota mengenai sistem yang sedang berjalan. Wawancara dilakukan dengan Ka Amin Firdaus selaku pelatih utama ranting perguruan, Adapun hasil wawancara menjelaskan bahwa sering terjadinya salah paham khususnya pada informasi organisasi yang ada dalam perguruan. Hal ini disebabkan karena sistem yang berjalan masih menggunakan cara lama atau manual yang seluruh pengolahan data mengandalkan form cetak dan tidak ada media informasi tetap untuk perguruan Keluarga Pencak Silat Nusantara ranting Gor Rawamangun dalam memberikan informasi terbaru secara online.

\section{c. Studi Pustaka}

Studi pustaka yang dilakukan penulis berupa pengumpulan data dengan cara mencari buku-buku referensi, tutorial atau bahan-bahan teori yang diperlukan dari berbagai sumber yang berkaitan dengan pembuatan tugas akhir.

3.2. Metode Analisis

\section{a. Analisis SWOT}

Analisa ini didasarkan pada hubungan antara unsur - unsur internal, yaitu kekuatan (strength) dan kelemahan (weakness), terhadap unsur - unsur eksternal yaitu peluang (opportunities) dan ancaman (treats).

Tabel 3. 1 Analisis SWOT

\begin{tabular}{|c|c|}
\hline STRENGTH (S) & WEAKNESS (W) \\
\hline $\begin{array}{l}\text { 1. Dukungan dari manajemen untuk } \\
\text { merancang sebuah sistem. } \\
\text { 2. Tersedianya komputer, printer dan } \\
\text { jaringan internet dapat } \\
\text { mempermudah pengolahan data, } \\
\text { juga pengaksesan informasi. }\end{array}$ & $\begin{array}{l}\text { 1. Pekerjaan yang tidak efektif dan } \\
\text { efisien karena masih ada yang } \\
\text { tidak benar input data } \\
\text { menyebabkan data diri diinput } \\
\text { ulang. } \\
\text { 2. Kurangnya pemberitahuan alur } \\
\text { atau cara daftar anggota, } \\
\text { menyebabkan ada yang melakukan } \\
\text { penginputan langsung tapi tidak } \\
\text { benar datanya. }\end{array}$ \\
\hline OPPURTUNITIES (O) & $\operatorname{THREATS}(\mathrm{T})$ \\
\hline
\end{tabular}


DOI: $10.52362 /$ jmijayakarta.v1i4.500

1. Membangun sistem keanggotaan silat secara online.

2. Sistem mempermudah proses penginputan data anggota silat.
1. Menciptakan sistem keanggotaan yang mudah dipahami dan menarik.

b. Analisa Sistem Berjalan

Analisa sistem yang sedang berjalan adalah tahap penguraian prosedur-prosedur yang berjalan didalam sistem, untuk memberikan penjelasan tentang tahap demi tahap yang terjadi pada setiap prosedur. Analisa sistem berjalan dilakukan dengan tujuan mengetahui proses kerja yang sedang berjalan. Hal ini dilakukan untuk mengevaluasi dan memberikan gambaran rencana pemecahan masalah yang dihadapi.

Kegiatan penginputan data keanggotaan yang sedang berjalan di KPSN ranting GOR Rawamangun memiliki tahapan-tahapan dalam melakukan proses kegiatannya. Tahapantahapan tersebut adalah sebagai berikut:

1. Pengarsipan data anggota per periode dilakukan dengan cara konvensional atau menggunakan kertas dan pulpen seadanya.

2. Proses penginputan data 1 ranting untuk terdaftar dalam perguruan membutuhkan waktu 3 hari.

Penyebaran informasi yang digunakan juga masih sangat sederhana yaitu dengan media cetak atau mulut ke mulut sehingga persebaran informasi sangat lambat dan kurang akurat yang mengakibatkan banyak anggota yang tidak mengetahui informasi yang telah beredar maupun salah paham tentang isi informasi.

3.3. Metode Pengembangan

Dalam model ini ada beberapa fase yang dapat dilihat pada Gambar Model Waterfall, model ini memiliki tahapan yang terdiri dari permulaan sistem, analisis sistem, perancangan sistem, dan implementasi sistem. Namun dalam penelitian ini penulisan hanya membahas tahap perancangan sistem, analisis sistem, dan implementasi sistem.

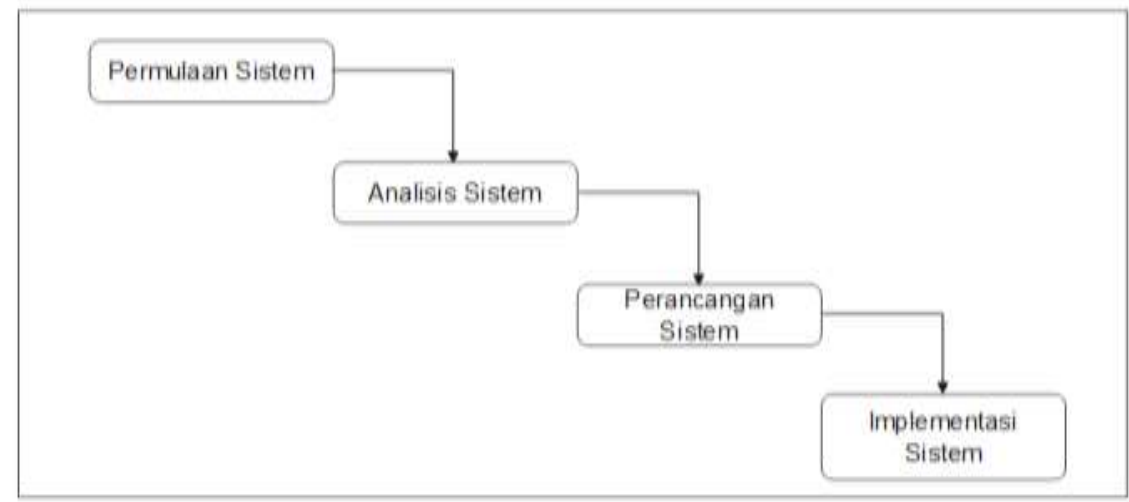

\section{Gambar 3. 1 Model Waterfall}

Berikut adalah tahapan yang dilakukan dengan menggunakan model waterfall :

1. Analisis Kebutuhan Sistem

Kebutuhan yang didapatkan dari hasil wawancara dengan Pelatih Silat dan Anggota

Silat di Keluarga Pencak Silat Nusantara ranting Gor Rawamangun dianalisa untuk mendapatkan kebutuhan sistem. Kebutuhan sistem ini kemudian dijadikan referensi untuk merancang sistem website.

2. Perancangan Sistem 


\section{DOI: $10.52362 /$ jmijayakarta.v1i4.500}

Setelah mendapatkan kebutuhan sistem didapatkan selanjutnya yaitu membuat atau merancang sistem menggunakan desain UML (Unified Modeling Lamguage).

3. Implementasi Sistem

Pada tahap ini pengujian aspek fungsionalitas dari perangkat lunak dimana fungsi fungsi yang harus disediakan akan diperiksa apakah telah sesuai spesifikasinya dengan yang diberikan oleh calon pengguna sistem dan dikembangkan kembali bila terjadi kekurangan.

3.4. Metode Perancangan

Pada sistem yang diusulkan terdapat 2 sistem login yaitu sistem login admin yang mana hanya admin yang dapat mengakses semua halaman sistem dan juga sistem login anggota yang juga hanya dapat diakses oleh anggota.

3.5. Metode Pengujian

Dalam metode pengujian ini, peneliti akan menggunakan pengujian terhadap program yang dibuat menggunakan pengujian UAT (User Acceptance Test) yang fokus terhadap proses masukan dan keluaran program yang meliputi :

a. Pengujian terhadap akses sistem admin

b. Pengujian terhadap akses sistem anggota

\section{HASIL DAN PEMBAHASAN (Results and Analysis)}

\subsection{Lokasi Penelitian}

penelitian dalam pembuatan sistem informasi manajemen keanggotaan ini adalah di Keluarga Pencak Silat Nusantara Ranting Gor Rawamangun, yang merupakan tempat pusat organisasi perguruan silat Keluarga Pencak Silat Nusantara (KPSN) di Jakarta Timur. Dikatakan pusat karena terdapat beberapa cabang yang tersedia sampai saat ini, diantaranya SD Negeri 06 Klender, SD Negeri 16 Duren Sawit, SMP Negeri 77 Jakarta, SMA Negeri 72 Jakarta dan SMA Al Ghurabaa.

4.2. Rancangan Use Case Diagram

Use Case Diagram merupakan model diagram UML yang digunakan untuk menggambarkan requirement fungsional yang diharapkan dari sebuah sistem. Use Case Diagram menekankan pada "siapa" melakukan "apa" dalam lingkungan sistem perangkat lunak yang akan dibangun.

Use Case Diagram dapat juga digunakan selama proses analisa untuk mendapatkan kebutuhan-kebutuhan (requirement) suatu sistem dan untuk merencanakan bagaimana sistem tersebut bekerja. Dalam sebuah sistem memungkinkan hanya terdapat satu atau beberapa Use Case. 
DOI: $10.52362 /$ jmijayakarta.v1i4.500

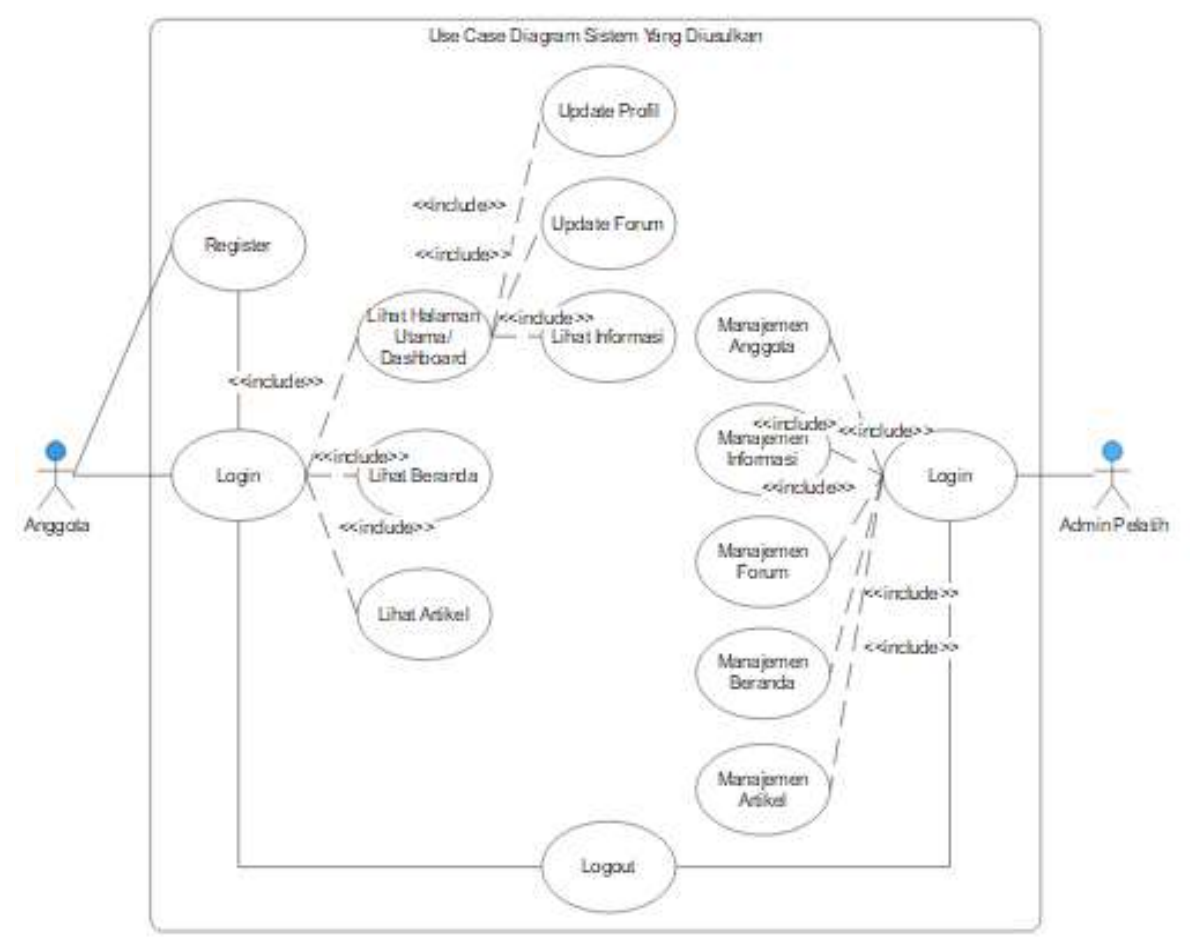

Gambar 4. 1 Use Case Diagram

4.3. Rancangan Activity Diagram

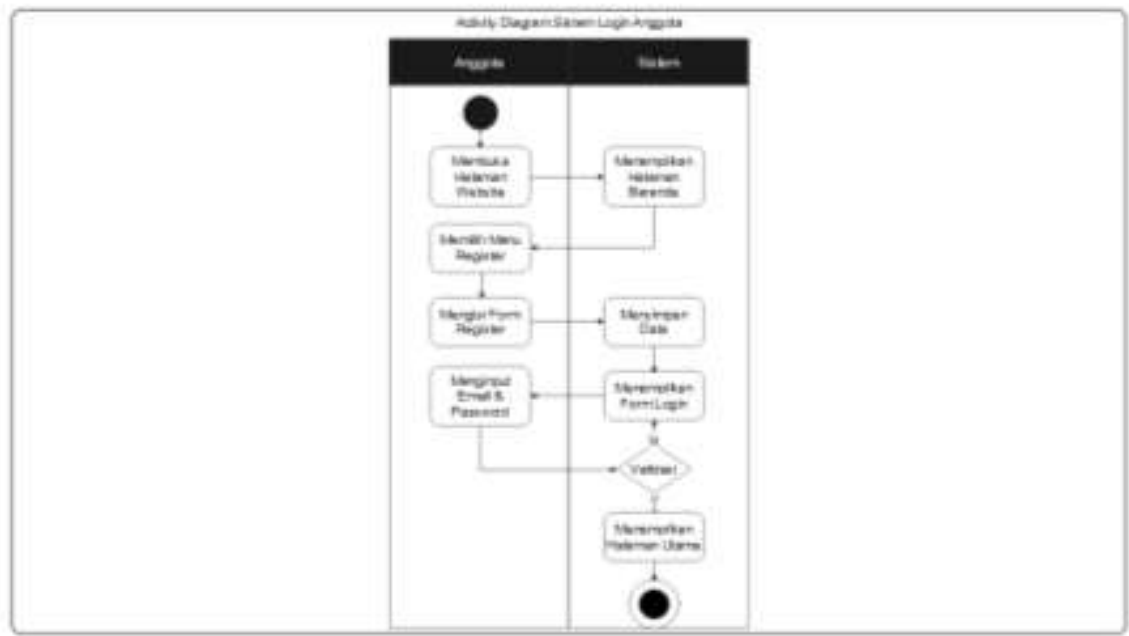

Gambar 4. 2 Activity Diagram Login Anggota

Berdasarkan Gambar 4.2 Activity Diagram Login Anggota :
a. Terdapat 1 innitial node yang menjelaskan status awal untuk mulai.
b. Terdapat 2 swimeline yaitu Anggota dan Sistem.
c. Terdapat 8 activity yang menggambarkan kegiatan proses login anggota
d. Terdapat activity final node yang menunjukkan status akhir yang dilakukan sistem. 
DOI: 10.52362/jmijayakarta.v1i4.500

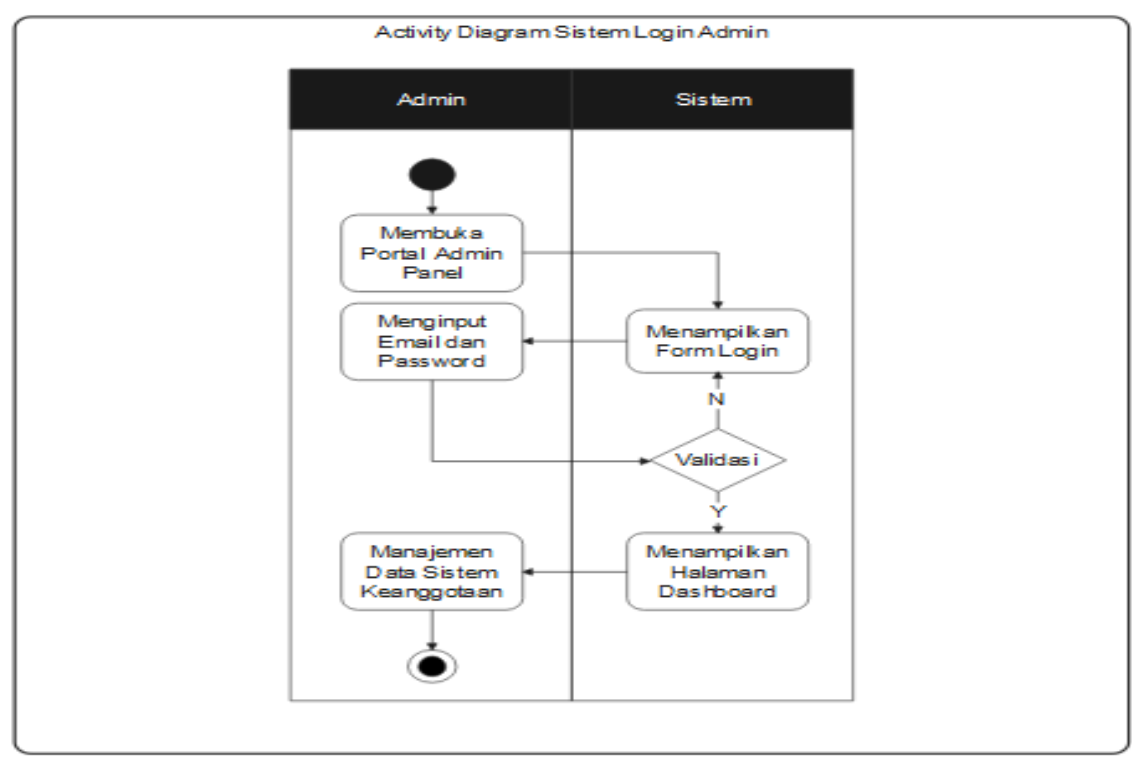

Gambar 4. 3 Activity Diagram Sistem Login Admin

Berdasarkan Gambar 4.3 Activity Diagram login admin :

a. Terdapat 1 innitial node yang menjelaskan status awal untuk mulai.

b. Terdapat 2 swimeline yaitu Admin dan Sistem.

c. Terdapat 6 activity yang menggambarkan proses kegiatan login admin.

d. Terdapat activity final node yang menunjukkan status akhir yang dilakukan sistem.

4.4. Rancangan Class Diagram

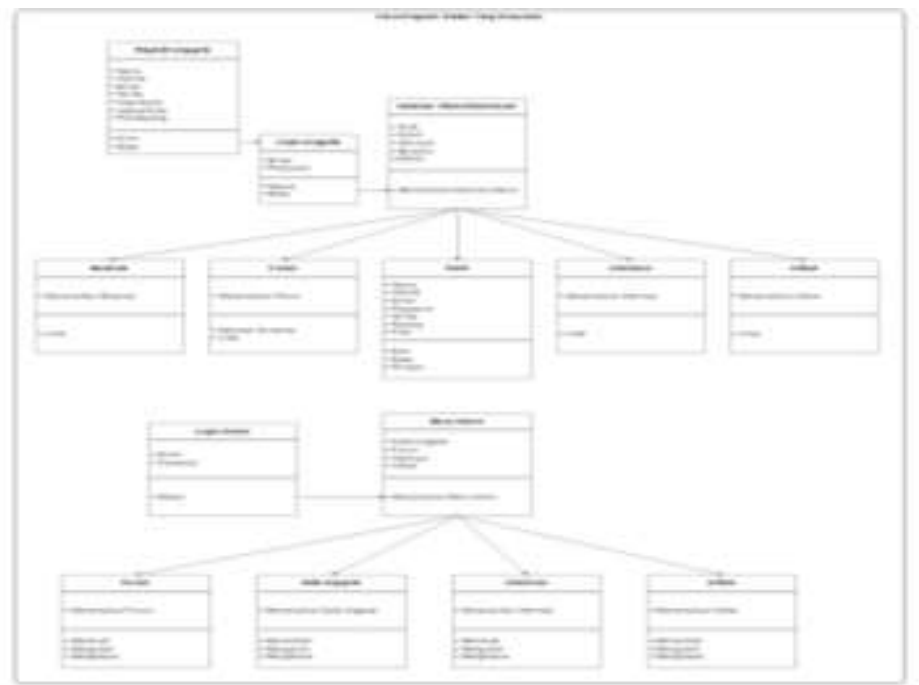

Gambar 4. 4 Class Diagram

Class diagram digunakan untuk menampilkan kelas-kelas dan paket-paket di dalam sistem. Class diagram memberikan gambaran sistem secara statis dan relasi antar mereka. Biasanya, dibuat beberapa class diagram untuk sistem tunggal. Beberapa diagram akan menampilkan subset dari kelas-kelas dan relasinya. Dapat dibuat beberapa diagram sesuai dengan yang diinginkan untuk mendapatkan gambaran lengkap terhadap sistem yang dibangun. 
DOI: 10.52362/jmijayakarta.v1i4.500

Class diagram adalah alat perancangan terbaik untuk tim pengembang. Diagram tersebut membantu pengembang mendapatkan struktur sistem sebelum kode ditulis, dan membantu untuk memastikan bahwa sistem adalah desain terbaik.

4.5. Implementasi Tampilan Input

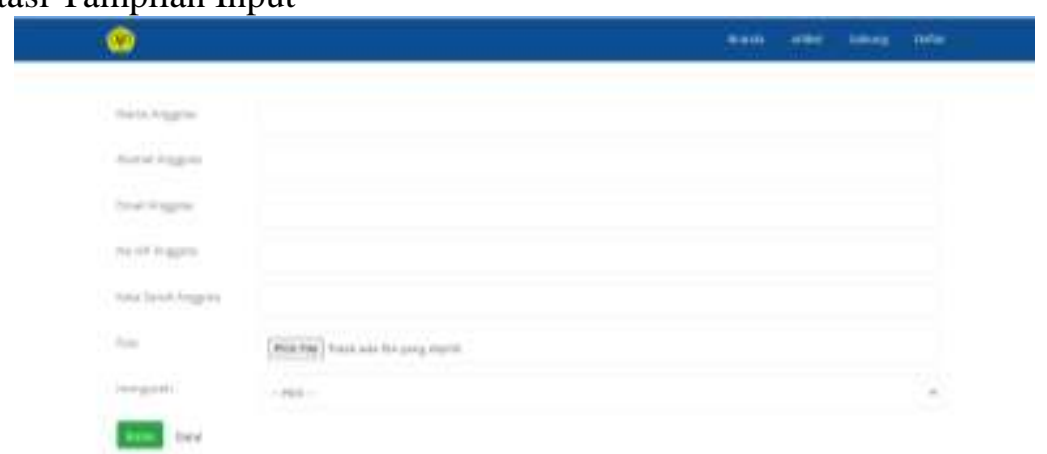

Gambar 4. 5 Tampilan Input Form Register

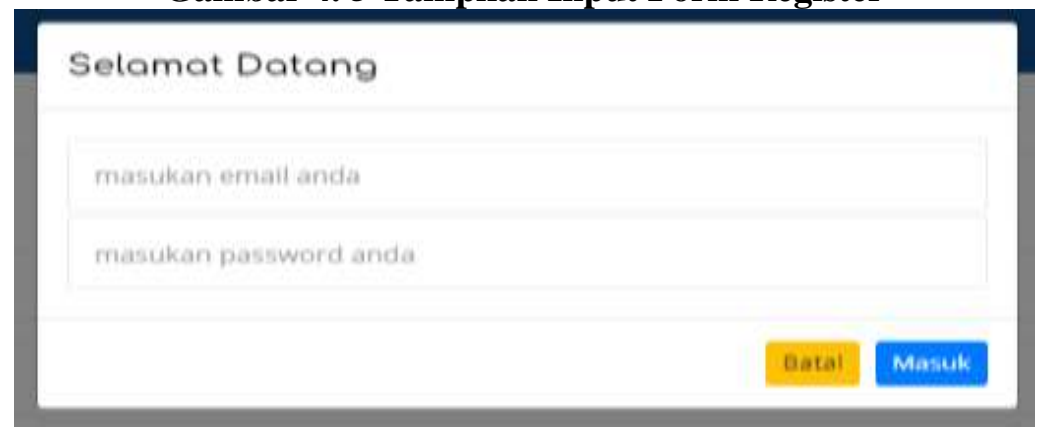

Gambar 4. 6 Tampilan Input Login Anggota
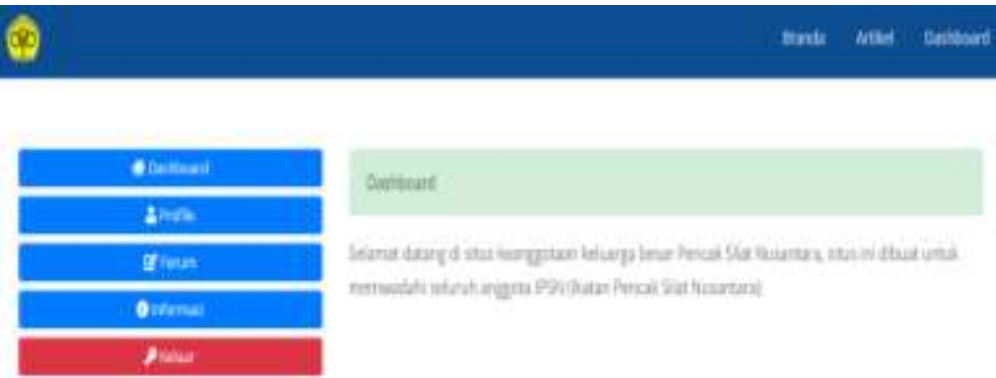

Gambar 4. 7 Tampilan Input Menu Anggota 
DOI: $10.52362 / j m i j a y a k a r t a . v 1 i 4.500$

4.6. Implementasi Tampilan Output

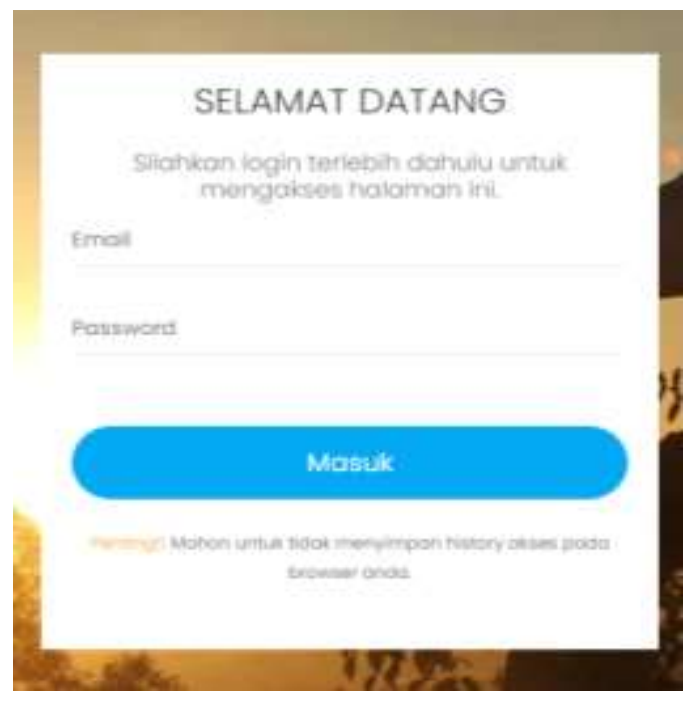

Gambar 4. 8 Tampilan Input Login Admin

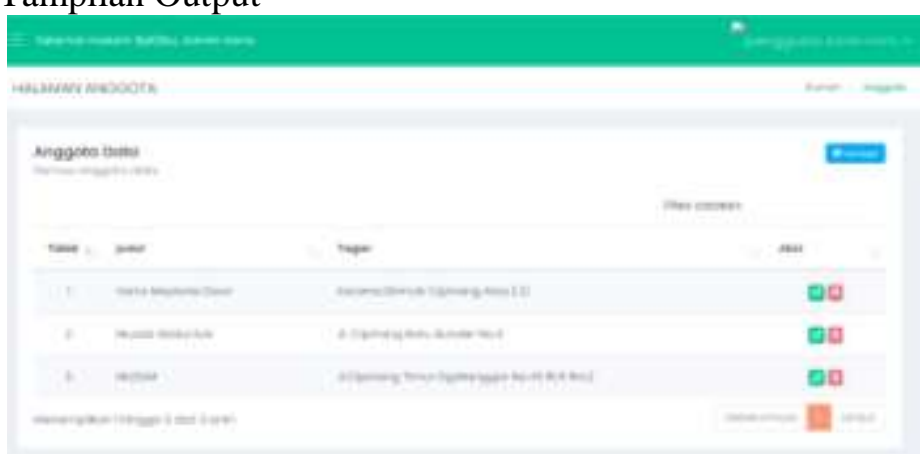

Gambar 4. 9 Tampilan Output Data Anggota

\subsection{Pengujian Aplikasi}

a. Pengujian 1 (UAT 1) pihak pelatih perguruan silat

Ditahap ini pihak KPSN ranting Gor Rawamangun melakukan pengujian sistem web yang dibuat, hasilnya sebagai berikut :

Penguji Pertama : Pelatih KPSN ranting Gor Rawamangun

Tabel 4. 1 UAT Pertama

\begin{tabular}{|l|l|l|}
\hline No. & \multicolumn{1}{|c|}{ Pengujian } & \multicolumn{1}{c|}{ Hasil } \\
\hline 1. & $\begin{array}{l}\text { Lakukan login menggunakan username dan } \\
\text { password }\end{array}$ & Berhasil \\
\hline 2. & Masuk ke halaman data forum & Berhasil \\
\hline 3. & Menambahkan forum baru & Berhasil \\
\hline 4. & Mengubah Isi forum & Berhasil \\
\hline 5. & Menghapus Forum & Berhasil \\
\hline 6. & Masuk ke halaman data artikel & Berhasil \\
\hline 7. & Menambahkan artikel baru & Berhasil \\
\hline 8. & Mengubah isi artikel & Berhasil \\
\hline 9. & Menghapus artikel & Berhasil \\
\hline 10. & Masuk ke halaman data anggota & Berhasil \\
\hline 11. & Menambahkan data anggota baru & Berhasil \\
\hline 12. & Mengubah data anggota & Berhasil \\
\hline
\end{tabular}


DOI: $10.52362 / j m i j a y a k a r t a . v 1 i 4.500$

\begin{tabular}{l|l|l}
\hline 13. & Menghapus data anggota & Berhasil \\
\hline
\end{tabular}

b. Pengujian 2 (UAT 2) pihak anggota perguruan silat

Ditahap ini pihak anggota melakukan pengujian pada situs web yang dibuat, hasilnya sebagai berikut :

Penguji Kedua : Muslimin Anggota Silat KPSN

Tabel 4. 2 UAT Kedua

\begin{tabular}{|l|l|l|}
\hline No. & Pengujian & Hasil \\
\hline 1. & Web bisa diakses & Berhasil \\
\hline 2. & Lakukan register & Berhasil \\
\hline 3. & $\begin{array}{l}\text { Lakukan log in menggunakan email dan } \\
\text { password }\end{array}$ & Berhasil \\
\hline 4. & Setelah login masuk ke halaman utama & Berhasil \\
\hline 5. & Memilih menu profil & Berhasil \\
\hline 6. & Mengubah profil & Berhasil \\
\hline 7. & Mengganti foto profil & Berhasil \\
\hline 8. & Memilih Ranting & Berhasil \\
\hline 9. & Memilih menu forum & Berhasil \\
\hline 10. & Menambahkan komentar forum & Berhasil \\
\hline 11. & Memilih menu informasi & Berhasil \\
\hline 12. & Memilih menu artikel & Berhasil \\
\hline
\end{tabular}

4.8. Hasil

Tabel 4. 3 Rekapitulasi Hasil

\begin{tabular}{|l|c|c|}
\hline \multirow{2}{*}{ Data } & \multicolumn{2}{|c|}{ Hasil Evaluasi } \\
\cline { 2 - 3 } & $\begin{array}{c}\text { Sebelum Uji } \\
\text { Coba Hasil }\end{array}$ & $\begin{array}{c}\text { Sesudah Uji Coba } \\
\text { Hasil }\end{array}$ \\
\hline Membuka Halaman Web & $65 \%$ & $97 \%$ \\
\hline Mendaftar pada form register & $60 \%$ & $97 \%$ \\
\hline $\begin{array}{l}\text { Login menggunakan email dan } \\
\text { password }\end{array}$ & $60 \%$ & $97 \%$ \\
\hline Melakukan edit profil & & \\
\hline Upload foto & $75 \%$ & $97 \%$ \\
\hline Membuka halaman forum & $65 \%$ & $97 \%$ \\
\hline Menambahkan komentar forum & $70 \%$ & $97 \%$ \\
\hline Membuka halaman informasi & $70 \%$ & $97 \%$ \\
\hline Membuka halaman artikel & $70 \%$ & $97 \%$ \\
\hline Membuka halaman beranda & $70 \%$ & $97 \%$ \\
\hline Logout & $70 \%$ & $97 \%$ \\
\hline
\end{tabular}

Berdasarkan hasil penelitian yang dilakukan penulis, maka didapatkan hasil sebagai berikut :

1. Telah dilakukan rancangan atas sistem keanggotaan perguruan silat yang dapat diakses oleh anggota silat guna untuk mempermudah pendataan oleh pelatih selaku pengelola sistem. 
DOI: $10.52362 / j m i j a y a k a r t a . v 1 i 4.500$

2. Dengan adanya sistem keanggotaan perguruan silat menjadi efektif dan efisien.

4.9. Solusi Hasil

Pada pembahasan ini penulis juga membuat solusi hasil sebagai berikut :

1. Tetap harus memberikan informasi kepada anggota secara lisan, karena anggota belum mengetahui informasi tentang adanya sistem keanggotaan dalam website.

2. Pelatih selaku pengelola sistem harus selalu ditingkatkan dalam sumber daya pengelola sehingga pengoperasian sistem terkomputerisasi lebih optimal.

\section{KESIMPULAN (Conclusion)}

5.1. Kesimpulan

Pada pembahasan yang telah diuraikan pada bab-bab sebelumnya dalam penulisan ini dapat disimpulkan tentang perancangan sistem keanggotaan perguruan silat berbasis website ini sebagai berikut :

1. Sistem informasi keanggotaan pada Keluarga Pencak Silat Nusantara ranting Gor Rawamangun dapat memberi kemudahan akses informasi serta proses pendataan bagi pelatih.

2. Dengan pembentukan sistem baru yang terkomputerisasi juga memudahkan para anggota untuk mendaftarkan data dirinya secara online agar lebih efektif dan efisien.

3. Dengan website ini juga para anggota dengan mudah mendapatkan informasi mengenai kegiatan dalam perguruan yang dimana nantinya akan dibagikan oleh pelatih secara online.

\subsection{Saran}

Berdasarkan hasil implementasi sistem informasi keanggotaan tersebut, berikut ini merupakan saran untuk pengembangan sistem selanjutnya, yaitu :

1. Untuk selanjutnya dapat dilakukan pembuatan sistem informasi keanggotaan berbasis android untuk lebih mempermudah dalam mengakses sistem informasi keanggotaan ini.

2. Menambahkan fitur-fitur baru yang belum ada seperti absensi anggota dan kas keuangan anggota.

\section{REFERENSI (Reference)}

[1] Bangsa, B., \& Semarang, S. (2012). Persepsi Pelajar Terhadap Pencak Silat Sebagai Warisan Budaya Bangsa Sekota Semarang Tahun 2012. ACTIVE: Journal of Physical Education, Sport, Health and Recreation, 1(3). https://doi.org/10.15294/active.v1i3.443

[2] Mulyadi. (2016). Definisi Sistem Informasi. Anastasia Diana \& Lilis Setiawati, tahun 2016, 7 25. http://eprints.polsri.ac.id/3564/

[3] Mulyadi. (2016). Definisi Sistem Informasi. Anastasia Diana \& Lilis Setiawati, tahun 2016, 7 25. http://eprints.polsri.ac.id/3564/

[4] Rahadian, F. (2020). PENGARUH PENERAPAN TOTAL QUALITY MANAGEMENT TERHADAP KEUNGGULAN BERSAING PADA PT. CINTA AIR MINUM Fajar. Jurnal Indonesia Membangun, 19(1), 57-71.

[5] Hanif Al Fatta. 2017. Analisis \& Perancangan Sistem Informasi. Penerbit Andi

[6] Wahyu Hidayat dkk. 2016. Perancangan Video Profile Sebagai Media Promosi Dan Informasi Di Smk Avicena Rajeg Tangerang. Online ISSN: 2655-2574. Print ISSN: 2461-1417

[7] Mulyani, Sri. 2016. Metode Analisis dan Perancangan Sistem. Bandung: Abdi Sistematika

[8] Abdulloh, Rohi. 2018. 7 in 1 Pemrograman Web untuk Pemula. Jakarta: Elex Media Komputindo.

[9] Solichin, Achmad. 2016. Pemrograman Web dengan PHP dan MySQL. Jakarta : Universitas Budi Luhur. 
DOI: $10.52362 / j m i j a y a k a r t a . v 1 i 4.500$

[10] Mulyani, Sri. 2016. Analisis dan Perancangan sistem Informasi Manajemen Keuangan Daerah: Notasi Pemodelan Unified Modeling Language(UML). Bandung: Abdi Sistematika

[11] Madcoms. 2016. Sukses Membangun Toko Online dengan PHP \& MySQL. Yogyakarta: Andi.

[12] Nurcholish, Ahmad. 2018. Membangun Database Arsip Persuratan Menggunakan Pemrograman PHP dan MySQL. Sukabumi: CV Jejak

[13] Dinata, F., \& Muchlis, A. F. (2019). Jurnal Stamina Jurnal Stamina. Jurnal Stamina, 2(BURU BABI DI KECAMATAN KAYU TANAM KABUPATEN PADANG PARIAMAN (Studi), 187-195.

[14] Pencak, P., Di, S., Tengah, J., Daerah, D. A. N., \& Yogyakarta, I. (2020). JURNAL. 15.

[15] Mulyana. (2013). pendidikan pencak silat: PT Remaja Rosdakarya.

[16] Wilson. 2015. Martial Arts and The Body Politic in Indonesia. Beaverton: Ringgold Inc. https://search.proquest.com/ docview/1688712754?accountid=38628 